AL-MARSHAD: JURNAL ASTRONOMI ISLAM DAN ILMU-ILMU BERKAITAN

ISSN 2442-5729 (print) || ISSN 2598-2559 (online), http://jurnal.umsu.ac.id/index.php/almarshad DOI: https://doi.org/10.30596/jam.v4i2.2140

Published December 2018

\title{
Prediksi Pergerakan Bayangan Bumi Saat Terjadi Gerhana Bulan Menggunakan Ephemeris Hisab Rukyat
}

\author{
Muhammad Farid Azmi ${ }^{1 *}$, Ahmad Adib Rofiuddin², Ahmad Ainul Yaqin ${ }^{3}$ \\ Mahasiswa Pascasarjana S2 Ilmu Falak UIN Walisongo \\ Email: mfaridazmi95@gmail.com
}

\begin{tabular}{l} 
Abstract \\
\hline In this era, The prediction of lunar eclipse can be determined \\
accurately with the astronomical data based algorithm. \\
Usually, the prediction just compute the position and time of \\
lunar eclipse without considered the movement of Earth \\
shadow in the begginning to the end of eclipse. In this \\
article the author explain how is the concept, algorithm, and \\
analysis about the movement of Earth shadow on going \\
lunar eclipse in certain local coordinate point, using the data \\
from Ephemeris Hisab Rukyat. \\
Keywords : Lunar Eclipse, Earth Shadow, Ephemeris \\
Hisab Rukyat
\end{tabular}

\begin{tabular}{l}
\hline Abstrak \\
\hline Persoalan penetapan awal bulan (khususnya Ramadhan, \\
Syawal dan Zulhijah) di Indonesia sampai hari ini tak \\
kunjung usai. Salah satu sebab persoalan pendefinisian hilal. \\
Diakui di Indonesia terdapat ragam pandangan dan pendapat \\
mengenai definisi hilal ini yang mana antara satu dengan \\
yang lain tampak bertentangan. Nahdlatul Ulama \\
mendefinisikan hilal harus terlihat (ruukyat), \\
Muhammadiyah mendefinisikan cukup dengan perhitungan \\
(hisab), dan Kementerian Agama (Pemerintah) \\
mendefinikan dengan kemungkinan terlihat (imkan rukyat). \\
Masing-masing pandangan ini memiliki kelebihan dan \\
kekurangan, dan masing-masing memiliki landasan dalil \\
syar'i dan ilmi masing-masing.
\end{tabular}

Kata Kunci: Hilal, Awal Bulan, Hisab-Ruyat

\section{A. Pendahuluan}

Gerhana Bulan merupakan

fenomena langit yang tidak dapat

dipisahkan dari masalah penentuan fase-

fase Bulan khususnya fase purnama, sebab gerhana bulan terjadi ketika
Artikel Info

Received:

16 September 2018

Revised:

16 Oktober 2018

Accepted:

23 November 2018 
Dalam perhitungan gerhana bulan, wajarnya hanya memprediksikan waktu gerhana dan posisi Bulan saat terjadinya gerhana, algoritma untuk mengetahui arah bayangan yang jatuh di Bulan tidak dijelaskan secara gamblang. Padahal prediksi ini sangat penting, guna untuk memperkirakan dari arah mana bayangan muncul dan perlahan bergerak menutupi cahaya purnama, sehingga diharapkan gerhana Bulan dapat disimulasikan secara detail dan jelas, dengan menampilkan ilustrasi arah bayangan masuk, lalu arah bayangan saat mulai beranjak terang dan arah bayangan terakhir menyentuh piringan Bulan.

$$
\text { Dari sinilah penulis }
$$
menjabarkan bagaimana konsep dan algoritma gerak bayangan Bumi berlaku di suatu tempat secara lokal saat terjadinya gerhana Bulan. Data astronomis yang digunakan penulis diambil dari buku Ephemeris Hisab Rukyat yang setiap tahun dikeluarkan oleh Kementerian Agama Republik Indonesia, kemudian diolah menggunakan rumus trigonometri bola untuk menghasilkan posisi bayangan Bumi ketika terjadi kontak-kontak gerhana, yakni pada saat awal gerhana, awal total, akhir total dan akhir gerhana, baik kontak umbra maupun penumbra. Disamping itu pula, akan dijelaskan konsep astronomi bola dari rumusrumus yang dijabarkan.

\section{B. Proses Gerhana Bulan.}

Gerhana merupakan persamaan kata eclipse (Inggris), atau ekleipsis (Yunani). Dalam sehari-hari gerhana dipergunakan untuk mendeskripsikan keadaan atau kejadian dimana pada saat itu terjadi kesuraman sesaat, maka dari itu gerhana juga berkonotasikan makna tersebut. $^{2}$ Gerhana Bulan mempunyai makna memasuki, berbeda dengan gerhana Matahari yang mempunyai makna menutupi. Dari dua makna tersebut, istilah dalam bahasa arab yang digunakan pun juga berbeda, untuk gerhana Matahari disebut kusüf sedang untuk gerhana Bulan disebut khusüf.

Gerhana Bulan adalah fenomena piringan Bulan memasuki kerucut bayangan Bumi, sehingga piringan Bulan nampak menjadi gelap. Fenomena ini hanya dapat terjadi ketika Bulan purnama dan Bulan berada dekat

\footnotetext{
2 Slamet Hambali, Pengantar Ilmu Falak, (Banyuwangi: Bismillah Publisher, 2012), h. 228.
} 
AL-MARSHAD: JURNAL ASTRONOMI ISLAM DAN ILMU-ILMU BERKAITAN

ISSN 2442-5729 (print) || ISSN 2598-2559 (online), http://jurnal.umsu.ac.id/index.php/almarshad DOI: https://doi.org/10.30596/jam.v4i2.2140

Published December 2018

dengan salah satu titik simpul naik (ascending node) atau titik simpul turun (descending node). ${ }^{3}$ Proses terjadinya gerhana Bulan tidak luput dari pergerakan Matahari, Bumi dan Bulan, khususnya revolusi antara Bumi dan Bulan. Ketika Bulan berada pada posisi 12 derajat atau kurang dari titik simpul maka dimungkinkan akan terjadi gerhana Bulan. ${ }^{4}$ Lebih perincinya yaitu ketika pusat bayangan Bumi terletak pada 10,9 derajat dari titik simpul. Ketika bayangan Bumi terletak pada 5,2 derajat dari titik simpul, maka dipastikan terjadi gerhana Bulan total, daerah 10,9 derajat ke Timur dan ke Barat titik simpul itulah dinamakan zona gerhana. $^{5}$

Sedangkan titik simpul adalah titik perpotongan antara bidang peredaran lintasan Bumi dan Bulan, dalam kenyataannya terdapat dua titik simpul yang ada di garis edar keduanya, lalu ketika dua titik itu diberi garis khayal, maka garis itu disebut dengan

3 Rinto Anugraha, Mekanika Benda Langit, (Yogyakarta : Universitas Gadjah Mada, 2012), h. 135

${ }^{4}$ Muhyiddin Khazin, Kamus Ilmu Falak, (Yogyakarta : Buana Pustaka, 2005), h. 45.

5 Ahmad Izzuddin, Ilmu Falak Praktis, (Semarang: PT. Pustaka Rizki Putra, 2012), h. 110. garis $\operatorname{simpul}^{6}{ }^{6}$ garis ini tidak tetap, namun selalu berputar seiring dengan berputarnya titik simpul dengan laju 19 derajat ke Barat dan Timur, dan kirakira 18 tahun 11 hari kemudian, garis tersebut kembali pada posisi semula, maka ketika itulah terjadi gerhana yang mirip dari gerhana sebelumnya. Pergeseran titik simpul inilah yang mengakibatkan musim gerhana terjadi dalam interval yang lebih pendek dari 6 bulan yaitu 173,3 hari, dua musim gerhana menyusun sebuah tahun gerhana yang lamanya 346,6 hari. Jadi akan lebih pendek 18,6 hari dibanding dengan satu tahun kalender Masehi. ${ }^{7}$

Bayangan yang dibentuk oleh Bumi mempunyai dua bagian, yakni bagian paling luar yang berwarna abuabu disebut penumbra dan bagian inti yang berwarna gelap disebut umbra. Kalau Bulan hanya melewati daerah bayang-bayang penumbra saja, maka gerhana itu disebut gerhana penumbra, namun sayangnya sangat sulit untuk melihat perbedaan terangnya Bulan ketika masih berada di luar bayangan penumbra dengan ketika sudah berada

\footnotetext{
${ }^{6}$ Slamet Hambali, Pengantar Ilmu Falak ,h. 230

${ }^{7}$ Ahmad Izzuddin, Ilmu Falak Praktis, h. 110.
} 
AL-MARSHAD: JURNAL ASTRONOMI ISLAM DAN ILMU-ILMU BERKAITAN

ISSN 2442-5729 (print) || ISSN 2598-2559 (online), http://jurnal.umsu.ac.id/index.php/almarshad DOI: https://doi.org/10.30596/jam.v4i2.2140

Published December 2018 di dalamnya, sebab intensitas kegelapannya kecil sekali, oleh karena itu gerhana seperti ini biasanya kurang menarik perhatian. Yang biasa dimaksud dengan gerhana Bulan itu ialah ketika Bulan memasuki bayangan umbra, gerhana seperti ini intensitas kegelapannya dapat diamati oleh mata. Jika piringan Bulan masuk seluruhnya disebut gerhana total dan jika sebagian saja disebut gerhana partial (sebagian). ${ }^{8}$

Jadi secara keseluruhan, dilihat dari piringan Bulan yang gelap akibat memasuki bayangan Bumi, dapat dibagi menjadi 4 tipe gerhana :

1. Gerhana Bulan Umbra Total yaitu ketika seluruh piringan Bulan masuk dalam bayangan umbra Bumi.

2. Gerhana Bulan Umbra Sebagian yaitu ketika sebagian piringan Bulan masuk bayangan umbra Bumi.

3. Gerhana Bulan Penumbra Total (Semu Total) yaitu ketika seluruh piringan Bulan masuk dalam bayangan penumbra Bumi.

4. Gerhana Bulan Penumbra Sebagian (Semu Sebagian) yaitu ketika

8 Badan Hisab \& Rukyat Departemen Agama, Almanak Hisab Rukyat, h. 146 sebagian piringan Bulan masuk dalam bayangan penumbra Bumi. ${ }^{9}$

Dalam gerhana Bulan secara sempurna terjadi 8 kontak gerhana, kontak-kontak ini merupakan waktu pertama kali piringan Bulan bersentuhan dengan bayangan penumbra atau umbra Bumi, baik pada saat masuk maupun keluar bayangan, 8 kontak tersebut adalah sebagai berikut :

1. P1 : ketika piringan Bulan mulai menyentuh masuk bayangan penumbra Bumi. Pada waktu inilah waktu mulai gerhana penumbra.

2. P2 : ketika piringan Bulan sudah masuk bayangan penumbra Bumi secara sempurna. Waktu ini adalah waktu mulai gerhana penumbra total, namun dalam perhitungan gerhana, P2 sering diabaikan dan tidak dihitung.

3. U1 : ketika piringan Bulan mulai menyentuh masuk bayangan umbra Bumi. Pada saat itu disebut waktu mulai gerhana umbra.

4. U2 : ketika piringan Bulan sudah masuk bayangan umbra secara

9 Ahmad Izzan, dkk, Studi Ilmu Falak, (Banten : Pustaka Aufa Media, 2013), h. 176177. 
AL-MARSHAD: JURNAL ASTRONOMI ISLAM DAN ILMU-ILMU BERKAITAN

ISSN 2442-5729 (print) || ISSN 2598-2559 (online), http://jurnal.umsu.ac.id/index.php/almarshad DOI: https://doi.org/10.30596/jam.v4i2.2140

Published December 2018

sempurna. Pada posisi inilah waktu mulai gerhana umbra total.

5. U3 : ketika piringan Bulan mulai menyentuh keluar bayangan umbra. Inilah yang disebut waktu akhir gerhana umbra total.

6. U4 : ketika piringan Bulan sudah keluar bayangan umbra secara sempurna. Pada posisi ini disebut waktu akhir gerhana umbra.

7. P3 : ketika piringan Bulan mulai menyentuh keluar bayangan penumbra. Pada saat ini disebut waktu akhir gerhana penumbra total. Sama halnya dengan kontak P2, dalam perhitungan gerhana, kontak P3 sering diabaikan dan tidak dihitung.

8. P4 : ketika piringan Bulan sudah keluar bayangan penumbra secara sempurna. Pada saat inilah disebut waktu akhir gerhana penumbra. ${ }^{10}$

Dalam proses gerhana Bulan umbra total terjadi 8 kali kontak secara sempurna, sedangkan gerhana Bulan umbra sebagian mengecualikan kontak U2 dan U3. Kemudian gerhana Bulan penumbra total hanya terjadi 4 kali

10 Muhyiddin Khazin, Ilmu Falak dalam Teori dan Praktik, (Yogyakarta: Buana Pustaka, 2004), h. 191-192. kontak, yakni P1, P2, P3 dan P4. Terakhir gerhana penumbra sebagian hanya 2 kali kontak saja, yaitu P1 dan P4.

\section{Konsep Prediksi Gerak Bayangan} Gerhana.

Prinsip dasar terjadinya gerhana Bulan adalah ketika Matahari, Bumi dan Bulan berada pada satu garis lurus yakni saat Bulan beroposisi. Digambarkan saat terjadinya gehana Bulan, sebenarnya piringan Bulan sedang memasuki bayangan Bumi. ${ }^{11}$ Bayangan ini terjadi karena posisi Matahari berkebalikan dengan posisi Bulan berada, oleh karena itu sering diungkapkan bahwa posisi Bulan dan Matahari selalu berselisih 180 derajat dari Bumi, ini membuktikan bahwa posisi antara keduanya adalah berhadaphadapan sehingga Bulan yang pada waktu itu dalam fase purnama terhalang cahayanya oleh Bumi, maka terjadilah gerhana Bulan. Dari teori dasar ini, penulis mengembangkannya untuk memprediksi gerak bayangan Bumi secara berkala, dari manakah arah bayangan Bumi mulai masuk dan keluar

${ }^{11}$ Ahmad Izzuddin, Ilmu Falak Praktis, h. 105. 
piringan Bulan, apakah dari samping kanan-kiri, atas-bawah ataukah justru serong. Hal inilah yang menjadi kajian dalam tulisan ini.

Perhitungan yang dipakai untuk mengetahui gerak bayangan Bumi adalah perhitungan posisi Bulan dan posisi Matahari secara berulang pada waktu referensi terjadinya gerhana Bulan yakni waktu awal penumbra, awal gerhana, awal total, akhir total, akhir gerhana dan akhir penumbra. Sistem koordinat yang dipakai adalah sistem koordinat horison, dengan inti pusat adalah posisi pengamat yang terletak di permukaan Bumi, ${ }^{12}$ sehingga posisi Bulan dan Matahari diketahui melalui pendefinisian nilai ketinggian dan azimut keduanya. Dengan kata lain, dalam sistem koordinat horison, posisi dan kedudukan suatu benda langit ditentukan oleh nilai azimut dan tinggi benda langit.

Azimut suatu benda langit adalah jarak sudut pada lingkaran horison diukur mulai dari titik utara ke arah timur atau searah jarum jam sampai ke perpotongan antara lingkaran horison dengan lingkaran vertikal yang

12 Rinto Anugraha, Mekanika Benda Langit, h. 53. melalui benda langit tersebut. Sedangkan pengertian ketinggian suatu benda langit adalah nilai busur pada lingkaran vertikal yang diukur dari titik perpotongan antara lingkaran horison dengan lingkaran vertikal ke arah obyek benda langit tersebut. ${ }^{13}$ Lihat pada gambar berikut:

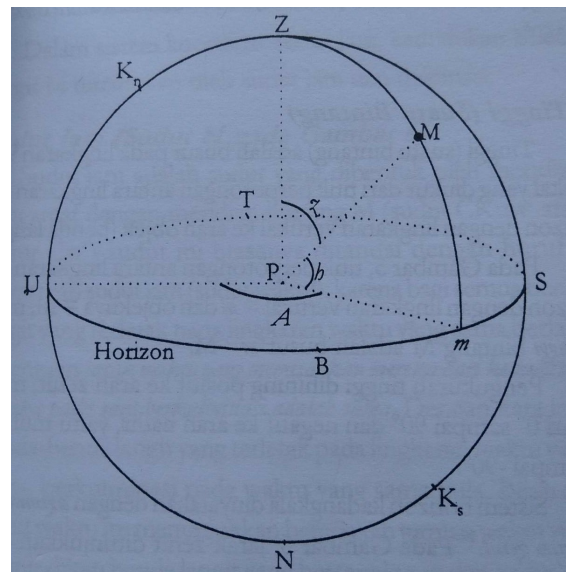

Gambar 1 : Koordinat Horison

Pada gambar di atas, titik $\mathrm{P}$ adalah posisi pengamat berada, sedangkan $\mathrm{M}$ merupakan benda langit yang diamati. Azimut benda langit $\mathrm{M}$, dihitung sepanjang garis horison mulai dari titik $U$ hingga titik $m$ melewati titik $\mathrm{T}$ dan titik $\mathrm{S}$. lalu ketinggian benda langit $\mathrm{M}$ diukur sepanjang garis vertikal dari titik $m$ ke titik M. Dengan uraian tersebut, dapat dinyatakan bahwa azimut titik utara adalah $0^{\circ}$, titik timur

13 Susiknan Azhari, Ilmu Falak Teori dan Praktek, (Yogyakarta: Lazuardi, 2001), h. 2830. 
AL-MARSHAD: JURNAL ASTRONOMI ISLAM DAN ILMU-ILMU BERKAITAN

ISSN 2442-5729 (print) || ISSN 2598-2559 (online), http://jurnal.umsu.ac.id/index.php/almarshad DOI: https://doi.org/10.30596/jam.v4i2.2140

Published December 2018 $90^{\circ}$, titik selatan $180^{\circ}$, titik barat $270^{\circ}$, dan nilai ketinggian maksimal dari suatu benda langit adalah $90^{\circ}$.

Konsep dasar dari posisi Matahari dan Bulan saat terjadi gerhana Bulan adalah keduanya saling berhadapan dilihat dari Bumi, jadi nilai azimut dan ketinggian antara Bulan dan Matahari selalu berkebalikan. Jika Matahari memancarkan sinar ke Bumi, maka dapat diproyeksikan posisi bayangan Bumi, yang mana selalu berkebalikan dengan posisi Matahari, kemudian seandainya posisi Bulan tepat pada posisi proyeksi bayangan Bumi tersebut, maka piringan Bulan yang bersinar akan tertutup oleh proyeksi bayangan Bumi, fenomena inilah yang mengakibatkan terjadinya gerhana Bulan.

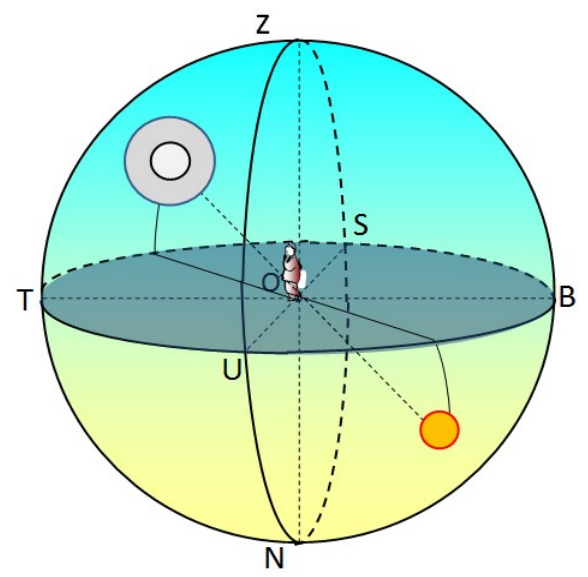

Gambar 2 : Proyeksi Bayangan Bumi
Dari gambar tersebut dapat diketahui bahwa posisi proyeksi bayangan Bumi didapat dari kebalikan posisi Matahari, jika ketinggian Matahari bernilai negatif, maka ketinggian proyeksi bayangan Bumi positif begitupun sebaliknya, sedangkan azimut proyeksi bayangan Bumi diketahui dengan menghitung azimut Matahari ditambah atau dikurangi $180^{\circ}$.

\section{Algoritma perhitungan Posisi} Bayangan Gerhana.

Dalam perhitungan berbasis data bessel, posisi Bulan sudah dapat dihitung dengan akurat, namun untuk metode ephemeris tidak demikian, perhitungan posisi Bulan tidak sertamerta diketahui begitu saja, karena dalam perhitungan gerhana sistem Ephemeris Hisab Rukyat hanya untuk mengetahui waktu gerhana, bukan untuk mengetahui posisi gerhana, oleh karena itu, dalam perhitungan gerak bayangan gerhana ini perlu data tambahan untuk mengetahui posisi Matahari dan Bulan. Data-data ephemeris yang diperlukan meliputi :

a. Deklinasi Matahari dan Bulan (Apparent Declination). 
AL-MARSHAD: JURNAL ASTRONOMI ISLAM DAN ILMU-ILMU BERKAITAN

ISSN 2442-5729 (print) || ISSN 2598-2559 (online), http://jurnal.umsu.ac.id/index.php/almarshad DOI: https://doi.org/10.30596/jam.v4i2.2140

Published December 2018

Deklinasi disebut juga mail, yakni jarak suatu benda langit sepanjang lingkaran deklinasi dihitung dari equator sampai benda langit yang diukur. Deklinasi bagi benda langit yang berada di sebelah utara equator tandanya positif $(+)$, dan bagi benda langit yang berada di sebelah selatan equator deklinasinya negatif (-). Dalam astronomi deklinasi sering dilambangkan dengan $\delta$ (delta). ${ }^{14}$

b. Equation Of Time.

Equation of time dalam bahasa arab disebut ta'dīl al-waqti, ta'dīl alzamān artinya perata waktu yakni selisih waktu antara waktu Matahari hakiki dengan waktu Matahari ratarata. ${ }^{15}$ Dalam astronomi equation of time sering disimbolkan dengan huruf e. Berhubungan dengan perhitungan ini, equation of time digunakan untuk mengkonversikan waktu daerah menjadi waktu hakiki.

c. Ascensio Rekta Matahari dan Bulan (Apparent Right Ascention).

Ascensio rekta disebut juga dengan istilah al-mathāli'u al-

\footnotetext{
${ }^{14}$ Muhyiddin Khazin, Kamus Ilmu Falak,
} h. 51

15 Ibid, h. 79 . balādiyyah adalah busur sepanjang lingkaran equator yang dihitung mulai dari titik Aries ke arah timur sampai titik perpotongan antara lingkaran equator dengan lingkaran deklinasi yang melalui benda langit tersebut. Dalam astronomi sering dilambangkan dengan $\alpha$ (alpha). ${ }^{16}$ Ascensio rekta Matahari dan Bulan sama-sama digunakan untuk menghitung sudut waktu Bulan ketika terjadinya gerhana.

Data-data ephemeris tersebut adalah sebagai data awal sebelum melakukan perhitungan, namun tak hanya itu, data lintang dan bujur tempat juga sangat diperlukan sebagai acuan koordinat lokasi mana yang akan dihitung. Dalam pengambilan data ephemeris perlu adanya interpolasi yang ditempuh dengan rumus : $\mathrm{A}-(\mathrm{A}-\mathrm{B}) \mathrm{x}$ C / I. ${ }^{17}$

Setalah melakukan interpolasi sesuai waktu yang dijadikan acuan dalam perhitungan (waktu saat terjadi gerhana), maka semua data-data ini dapat diolah dengan algoritma berikut:

a. Menghitung Sudut Waktu Matahari $\left(t_{0}\right)$. 
$\mathrm{t}_{\mathrm{o}}=(\mathrm{WD}+\mathrm{e}-(\mathrm{BD}-\lambda) / 15-12)$

x 15 atau dengan rumus lain,

$\mathrm{t}_{\mathrm{o}}=(\mathrm{WD}+\mathrm{e}) \times 15-\mathrm{BD}+\lambda-180$

WD adalah waktu daerah, dalam kontek perhitungan ini waktu daerah ialah waktu saat terjadinya gerhana (awal penumbra, awal gerhana, awal total, akhir total, akhir gerhana dan akhir penumbra). Lambang $\lambda$ (lamba) adalah simbol untuk data bujur tempat, sedangkan BD adalah bujur daerah. Untuk nilai bujur daerah pada zona WIB = $105^{\circ}$, WITA $=120^{\circ}$, WIT $=135^{\circ} .{ }^{18}$

b. Menghitung Ketinggian Matahari $\left(h_{0}\right)$.

$\operatorname{Sin} h_{o}=\sin \varphi \cdot \sin \delta_{o}+\cos \varphi \cdot \cos$ $\delta_{0} \cdot \cos \left[t_{0}\right]$

Lambang $\varphi$ (phi) adalah simbol untuk data lintang tempat, sedangkan $\delta_{\mathrm{o}}$ menunjukkan data deklinasi, lebih tepatnya deklinasi Matahari. ${ }^{19}$ Hasil perhitungan ketinggian Matahari harus dibalik tandanya, untuk memproyeksikan ketinggian bayangan Bumi di koordinat terhitung. Ketinggian

\footnotetext{
${ }^{18}$ Ahmad Izzuddin, Ilmu Falak Praktis, h. 58.

19 Abdur Rachim, Perhitungan Awal Bulan, (Yogyakarta: Jogja Astronomi Club, tth), h.11.
}

Matahari selalu bernilai negatif, karena gerhana Bulan selalu terjadi pada saat malam hari, sehingga untuk memproyeksikan ketinggian bayangan Bumi, hasil ketinggian Matahari harus dipositifkan, maka hasil tersebut adalah proyeksi ketinggian bayangan Bumi.

c. Menghitung Arah Matahari $\left(\mathrm{A}_{\mathrm{o}}\right)$.

$\operatorname{Cotan} \mathrm{A}_{\mathrm{o}}=\tan \delta_{\mathrm{o}} \cdot \cos \varphi / \sin \left[\mathrm{t}_{\mathrm{o}}\right]-$ $\sin \varphi / \tan \left[\mathrm{t}_{\mathrm{o}}\right]$

Jika hasil $A_{o}$ positif dan $t_{o}$ negatif maka $A_{o}=U T$, jika $A_{o}$ positif dan $t_{o}$ positif maka $A_{o}=U B$, jika $A_{o}$ negatif dan $t_{0}$ negatif maka $A_{0}=$ ST, jika $A_{o}$ negatif dan $t_{o}$ positif maka $\mathrm{A}_{\mathrm{o}}=\mathrm{SB}$.

Azimut Matahari dapat diketahui dengan ketentuan-ketentuan :

Jika $\mathrm{A}_{\mathrm{o}}=\mathrm{UT}$, maka Azimut $=$ $\mathrm{A}_{\mathrm{o}}$

Jika $\mathrm{A}_{\mathrm{o}}=\mathrm{ST}$, maka Azimut $=$ $180+\mathrm{A}_{\mathrm{o}}$

$>$ Jika $\mathrm{A}_{\mathrm{o}}=\mathrm{SB}$, maka Azimut $=$ $180-\mathrm{A}_{\mathrm{o}}$

$>$ Jika $\mathrm{A}_{\mathrm{o}}=\mathrm{UB}$, maka Azimut $=$ $360-\mathrm{Ao}{ }^{20}$ 
AL-MARSHAD: JURNAL ASTRONOMI ISLAM DAN ILMU-ILMU BERKAITAN

ISSN 2442-5729 (print) || ISSN 2598-2559 (online), http://jurnal.umsu.ac.id/index.php/almarshad DOI: https://doi.org/10.30596/jam.v4i2.2140

Published December 2018

Azimut Matahari kemudian

dikurangi atau ditambah $180^{\circ}$, maka hasilnya adalah azimut proyeksi bayangan Bumi, seperti yang telah diketahui, azimut bayangan suatu benda, selalu bertolak belakang dengan azimut Matahari, sehingga azimut bayangan Bumi dapat diketahui dengan cara membalik arahnya sebesar $180^{\circ}$.

d. Menghitung Sudut Waktu Bulan ( $\left.\mathrm{t}_{(}\right)$ $t_{(}=\alpha_{o}+t_{0}-\alpha_{c}$ $\alpha_{o}$ adalah data ascensio rekta Matahari, sedangkan $\alpha_{(}$merupakan data ascensio rekta Bulan. ${ }^{21}$

e. Menghitung Ketinggian Bulan $\left(\mathrm{h}_{(}\right)$.

$\operatorname{Sin} \mathrm{h}_{\mathrm{C}}=\sin \varphi \cdot \sin \delta_{\mathrm{C}}+\cos \varphi \cdot \cos \delta_{(}$. $\cos [\mathrm{t}]$

Lambang $\varphi$ (phi) adalah simbol untuk data lintang tempat, sedangkan $\delta_{(}$menunjukkan data deklinasi Bulan. Ketinggian Bulan harus bernilai positif, karena menunjukkan ketinggian Bulan ada di atas ufuk, sehingga gerhana Bulan dapat dilihat di koordinat terhitung.

f. Menghitung Azimut Bulan $\left(\mathrm{A}_{(}\right)$ $\operatorname{Cotan} \mathrm{A}_{\mathrm{C}}=\tan \delta_{(} \cdot \cos \varphi / \sin \left[\mathrm{t}_{\mathrm{C}}\right]-$ $\sin \varphi / \tan \left[\mathrm{t}_{]}\right]$ 100.
Arah Bulan dapat ditentukan dari nilai deklinasi dan perkiraan posisi Bulan dari titik zenit, jika deklinasi Bulan berada di selatan lintang tempat, maka arah bulan dihitung dari selatan, jika deklinasi Bulan berada di utara lintang tempat, maka arah Bulan dihitung dari utara.

Jika Bulan belum melewati titik zenit maka arah Bulan dihitung ke timur, jika Bulan sudah melewati titik zenit maka arah Bulan dihitung ke barat.

Azimut Bulan diketahui dengan menggunakan ketentuan-ketentuan :

Jika $\mathrm{A}_{(}=\mathrm{UT}$, maka Azimut $=\mathrm{A}_{(}$

$>$ Jika $\mathrm{A}_{(}=\mathrm{ST}$, maka Azimut $=$ $180+\mathrm{A}_{(}$

Dika $\mathrm{A}_{(}=\mathrm{SB}$, maka Azimut $=$ $180-\mathrm{A}_{(}$

Jika $A_{(}=U B$, maka Azimut $=$ $360-\mathrm{A}_{\text {( }}$

Setelah hasil tinggi dan azimut keduanya sudah diketahui, untuk lebih mudahnya posisi Bulan dan proyeksi posisi bayangan Bumi dapat divisualisasikan berdasarkan data ketinggian dan azimut sebagaimana yang telah dihitung, namun perlu dipahami bahwa proyeki bayangan Bumi selalu lebih besar dari pada piringan Matahari, jadi dalam 
visualisasi nilai semi diameter bayangan

lebih besar dari rata-rata semi diameter Matahari, yakni $0^{\circ} 16^{\prime}$. Dari visualisasi inilah arah kemunculan dan keluarnya gerhana dapat diketahui. Jika yang dihitung adalah waktu awal atau akhir gerhana, maka yang dihasilkan adalah arah muncul atau hilangnya gerhana, jika yang dihitung adalah waktu awal atau akhir total maka hasilnya adalah arah habis atau munculnya cahaya.

Berdasarkan visuslisasi yang dapat dilakukan, terdapat delapan kemungkinan posisi proyeksi bayangan Bumi dari piringan Bulan. Dilihat dari ketinggian dan azimut keduanya dapat disimpulkan sebagai berikut :

1. Jika tinggi proyeksi bayangan Bumi < tinggi Bulan dan azimut proyeksi bayangan $\mathrm{Bumi}=$ azimut Bulan, maka arah bayangan gerhana berada di bawah piringan Bulan

2. Jika tinggi proyeksi bayangan Bumi > tinggi Bulan dan azimut proyeksi bayangan Bumi $=$ azimut Bulan, maka bayangan gerhana berada di atas piringan Bulan

3. Jika tinggi proyeksi bayangan Bumi $=$ tinggi Bulan dan azimut proyeksi bayangan Bumi $<$ azimut
Bulan, maka bayangan gerhana berada di sisi kiri piringan Bulan

4. Jika tinggi proyeksi bayangan Bumi $=$ tinggi Bulan dan azimut proyeksi bayangan Bumi > azimut Bulan, maka bayangan gerhana berada di sisi kanan piringan Bulan

5. Jika tinggi proyeksi bayangan Bumi < tinggi Bulan dan azimut proyeksi bayangan Bumi < azimut Bulan, maka bayangan gerhana berada di sisi kiri condong ke bawah dari piringan Bulan.

6. Jika tinggi proyeksi bayangan Bumi > tinggi Bulan dan azimut proyeksi bayangan Bumi $>$ azimut Bulan, maka bayangan gerhana berada di sisi kanan condong ke atas dari piringan Bulan.

7. Jika tinggi proyeksi bayangan Bumi < tinggi Bulan dan azimut proyeksi bayangan Bumi > azimut Bulan, maka bayangan gerhana berada di sisi kanan condong ke bawah dari piringan Bulan.

8. Jika tinggi proyeksi bayangan Bumi > tinggi Bulan dan azimut proyeksi bayangan Bumi $<$ azimut Bulan, maka bayangan gerhana 
AL-MARSHAD: JURNAL ASTRONOMI ISLAM DAN ILMU-ILMU BERKAITAN

ISSN 2442-5729 (print) || ISSN 2598-2559 (online), http://jurnal.umsu.ac.id/index.php/almarshad DOI: https://doi.org/10.30596/jam.v4i2.2140

Published December 2018

berada di sisi kiri condong ke atas

dari piringan Bulan.

\section{E. Astronomi Bola Perhitungan}

\section{Posisi Bayangan Gerhana.}

Seperti yang telah dijelaskan, perhitungan posisi proyeksi bayangan Bumi meliputi dua rumus, yakni ketinggian dan azimut benda langit, rumus-rumus tersebut dapat dijelaskan dengan prinsip-prinsip trigonometri bola, menggunakan formula dasar cosinus dan formula dasar sinus. Lihat gambar berikut :

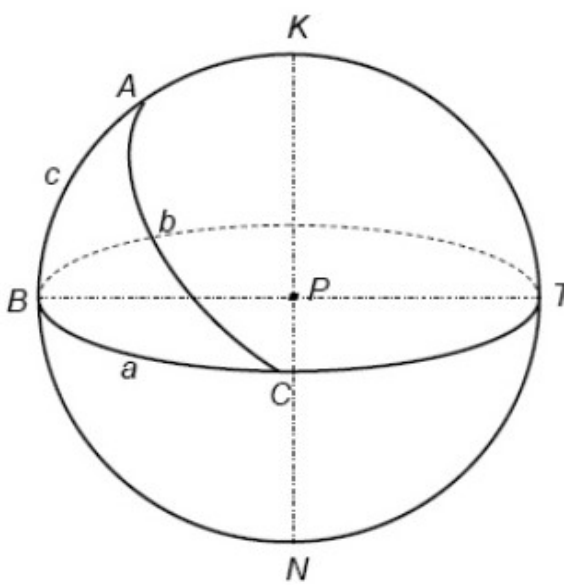

Gambar 3 : Segitiga bola.

Dalam gambar tersebut ada 6 variabel sebagai komponen dari segitiga bola, yakni sudut A, B, C dan sisi a, b, c. Dalam segitiga bola itu, dapat ditarik beberapa formula perhitungan sebagai berikut :

a. Rumus dasar sinus.

$$
\frac{\sin a}{\sin A}=\frac{\sin b}{\sin B}=\frac{\sin C}{\sin C}
$$

b. Rumus dasar cosinus

$\operatorname{Cos} a=\cos b \cos c+\sin b \sin c \cos A$

$\mathrm{Cos} b=\cos a \cos c+\sin a \sin c \cos B$

$\operatorname{Cos} c=\cos a \cos b+\sin a \sin b \cos$

C. ${ }^{22}$

Dua rumus dasar tersebut dapat digunakan untuk memecahkan formula ketinggian dan azimut benda langit. Ada tiga input data pada masing-masing formula, yaitu lintang tempat, deklinasi benda langit dan sudut waktu benda langit. Mudahnya, hal ini dapat dipahami dengan penggambaran berikut:

a. Ketinggian benda langit.

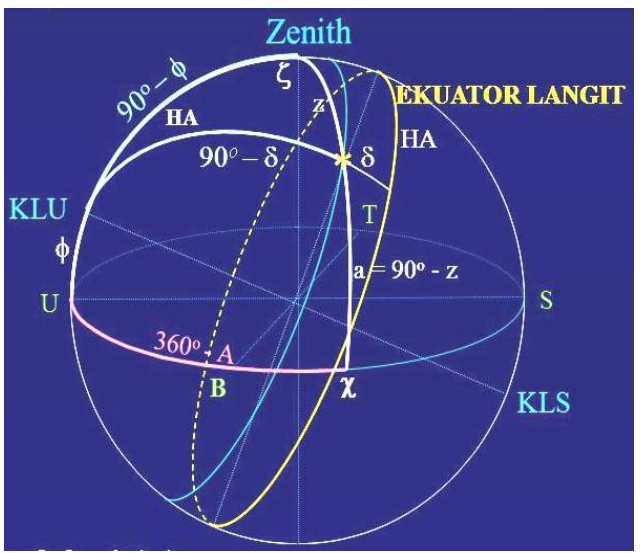

Gambar 4 : Trigonometri Altitude.

Complement lintang tempat (90-

$\varphi)$ di dalam gambar tersebut, didefinisikan sebagai komponen sisi,

22 A. Jamil, Ilmu Falak Teori \& Aplikasi, (Jakarta : Amzah, 2014), h. 56. 
begitu pula complement deklinasi benda langit (90- $\delta$ ) dan tinggi benda langit (a) yang merupakan compement dari sisi z. Sedangkan definisi sudut waktu (HA) adalah sebuah sudut yang berhadapan dengan $\mathrm{z}$, sehingga tinggi benda langit (a) dapat diketahui dengan rumus dasar cosinus :

$\operatorname{Cos} a=\cos b \cos c+\sin b \sin c \cos A$ Dimasukkan dalam penggambaran di atas :

$\operatorname{Cos}(90-a)=\cos (90-\varphi) \cos (90-\delta)+\sin$ $(90-\varphi) \sin (90-\delta) \cos \mathrm{HA}$

$\operatorname{Sin} \mathrm{a}=\sin \varphi \sin \delta+\cos \varphi \cos \delta \cos \mathrm{HA}$ b. Azimut benda langit.

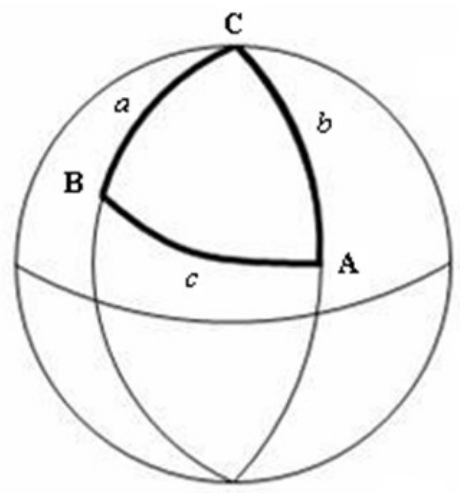

Gambar 5 : Trigonometri Azimut.

Titik A adalah tempat pengamat berada, titik B merupakan posisi benda langit, sedangkan titik $\mathrm{C}$ adalah kutub utara sejati. Definisi azimut (arah) benda langit dalam penggambaran tersebut adalah sudut A, sisi a yang berhadapan dengan sudut $A$ ialah complement deklinasi benda langit, sisi b ialah complement lintang tempat dan sudut $\mathrm{C}$ adalah sudut waktu benda langit. Sudut A dapat dicari jika sisi c sudah diketahui, oleh karena itu sisi c harus dihitung terlebih dahulu. Sisi c berhadapan dengan sudut $\mathrm{C}$ yang telah diketahui, sedangkan sudut $\mathrm{C}$ diapit sisi a dan sisi b yang juga telah diketahui nilainya, dari tiga komponen tersebut sisi c dapat dicari menggunakan rumus dasar cosinus berikut :

$C \cos c=\cos a \cos b+\sin a \sin b \cos C$

Dimasukkan sesuai penjabaran di atas, menjadi :

$\operatorname{Cos} c=\cos (90-\delta) \cos (90-\varphi)+\sin (90-$

$\delta) \sin (90-\varphi) \cos \mathrm{HA}$

$\operatorname{Cos} \mathrm{c}=\sin \delta \sin \varphi+\cos \delta \cos \varphi \cos$

HA

Setelah sisi c diketahui, maka sudut A (sudut arah benda langit) dapat dicari dengan formula dasar sinus :

$\frac{\sin a}{\sin A}=\frac{\sin C}{\sin C}$

Dari perbandingan tersebut $\sin a$ dipindah ruas ke kanan, menjadi :

$\operatorname{Sin} \mathrm{A}=\sin \mathrm{C} / \sin \mathrm{C} \mathrm{x} \sin \mathrm{a}$

Dimasukkan sesuai penggambaran di atas, menjadi :

$\operatorname{Sin} \mathrm{A}=\sin \mathrm{HA} / \sin \mathrm{c} \mathrm{x} \sin (90-\delta)$

$\operatorname{Sin} \mathrm{A}=\sin \mathrm{HA} / \sin \mathrm{c} \mathrm{x} \cos \delta$ 
AL-MARSHAD: JURNAL ASTRONOMI ISLAM DAN ILMU-ILMU BERKAITAN

ISSN 2442-5729 (print) || ISSN 2598-2559 (online), http://jurnal.umsu.ac.id/index.php/almarshad DOI: https://doi.org/10.30596/jam.v4i2.2140

Published December 2018
Dari dua rumus tersebut dapat ditranformasikan dalam rumus cotangen:

$\operatorname{Cotan} \mathrm{A}=\tan \delta \cdot \cos \varphi / \sin \mathrm{t}-\sin \varphi /$ $\tan \mathrm{t}$

\section{F. Perhitungan Posisi Bayangan Gerhana}

Prediksi arah kemunculan bayangan umbra gerhana Bulan pada 28 Juli 2018 M.

Markaz $=$ Semarang

Lintang Tempat $=-7^{\circ} \mathrm{LS}$

Bujur Tempat $=110^{\circ} 24^{\prime}$ BT

Bujur Daerah $=105^{\circ}$

Waktu Daerah (mulai gerhana) = 01:24:25 WIB $=18: 24: 25$ UT tanggal 27 Juli 2018 M.

a. Menghitung Interpolasi Data Ephemeris Hisab Rukyat.

$\mathrm{C}=18: 24: 25 \mathrm{UT}-18=00: 24: 25$

UT

Dek. Matahari Jam $18=19^{\circ} 05^{\prime}$ $47^{\prime 23}$

Dek. Matahari Jam $19=19^{\circ} 05^{\prime}$ $13 ”$

${ }^{23}$ Data deklinasi Matahari dan equation of time diambil dari buku Direktorat Urusan Agama Islam dan Bimbingan Islam Kementerian Agama RI, Ephemeris Hisab Rukyat 2018, (Jakarta : Kemenag RI, 2017), h. 226.
Interpolasi Dek Matahari $=\delta_{1}-\left(\delta_{1}\right.$

$\left.-\delta_{2}\right) \times \mathrm{C}$

$=19^{\circ} 05^{\prime} 47^{\prime \prime}-\left(19^{\circ} 05^{\prime} 47^{\prime \prime}-19^{\circ}\right.$

05 ' 13 ” ) x 00:24:25

$=19^{\circ} 5^{\prime} 33,16^{\prime \prime}$

Eq. Of Time Jam 18=-0 6' 32”

Eq. Of Time Jam 19=-0 6' 32"

Interpolasi Eq. Of Time $=\mathrm{e}_{1}-\left(\mathrm{e}_{1}\right.$

$\left.-\mathrm{e}_{2}\right) \times \mathrm{C}$

$=-0^{\circ} 6^{\prime} 32^{\prime \prime}-\left(-0^{\circ} 6^{\prime} 32^{\prime \prime}-0^{\circ} 6^{\prime}\right.$

$32 ”)$ x 00:24:25

$=-0^{\circ} 6^{\prime} 32^{\prime \prime}$

Ascen. Rek. Mat. Jam $18=126^{\circ}$

$59^{\prime} 38^{\prime \prime}$

Ascen. Rek. Mat. Jam 19=127 02'06”'

Interpolasi Asc. Rek Mat $=\alpha_{1}-$ $\left(\alpha_{1}-\alpha_{2}\right) \times C$

$=126^{\circ} 59^{\prime} 38^{\prime \prime}-\left(126^{\circ} 59^{\prime} 38^{\prime \prime}-\right.$

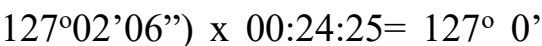

38,23 ”

Dek. Bulan Jam 18=-19 8' 40'

Dek. Bulan Jam 19=-19 4’25”

Interpolasi Dek. Bulan $=\delta_{1}-\left(\delta_{1}\right.$

$\left.-\delta_{2}\right) \times \mathrm{C}$

$=-19^{\circ} 8^{\prime} 40^{\prime \prime}-\left(-19^{\circ} 8^{\prime} 40^{\prime \prime}--19^{\circ}\right.$

4' 25 ") x 00:24:25

$=-19^{\circ} 6^{\prime} 56,23^{\prime \prime}$

Ascen. Rek. Bln Jam 18 $=305^{\circ}$

50 ' 24 '” 
Ascen. Rek. Bln Jam 19= $306^{\circ}$

$21^{\prime} 26$ "'

Interpolasi Asc. Rek. Bln= $\alpha_{1}-$

$\left(\alpha_{1}-\alpha_{2}\right) \times C$

$=305^{\circ} 50$ '24” $-\left(305^{\circ} 50\right.$ '24” -

$\left.306^{\circ} 21^{\prime} 26^{\prime \prime}\right)$ x 00:24:25

$=306^{\circ} 3^{\prime} 1,73^{\prime \prime}$

b. Menghitung Sudut Waktu

Matahari $\left(\mathrm{t}_{\mathrm{o}}\right)$.

$\mathrm{t}_{\mathrm{o}}=(\mathrm{WD}+\mathrm{e}) \times 15-\mathrm{BD}+\lambda-$

180

$\mathrm{t}_{\mathrm{o}}=\left(01: 24: 25+-0^{\circ} 6^{\prime} 32^{\prime \prime}\right) \times 15-$

$105^{\circ}+110^{\circ} 24^{\prime}-180$

$\mathrm{t}_{\mathrm{o}}=-155^{\circ} 7^{\prime} 45^{\prime \prime}$

c. Menghitung Ketinggian Matahari $\left(h_{0}\right)$.

$\operatorname{Sin} h_{o}=\sin \varphi \cdot \sin \delta_{o}+\cos \varphi \cdot \cos$

$\delta_{\mathrm{o}} \cdot \cos \left[\mathrm{t}_{\mathrm{o}}\right]$

$\operatorname{Sin} \mathrm{h}_{\mathrm{o}}=\sin -^{\circ} \cdot \sin 19^{\circ} 5^{\prime} 33,16^{\prime \prime}$

$+\cos -7^{\circ} \cdot \cos 19^{\circ} 5^{\prime} 33,16^{\prime \prime} \cdot \cos$

$\left[-155^{\circ} 7,45^{\prime \prime}\right]$

$\mathrm{h}_{\mathrm{o}}=-62^{\circ} 58^{\prime} 36,91$ ” di bawah

ufuk

Ketinggian bayangan umbra

selalu berkebalikan dengan

ketinggian Matahari, sehingga

ketinggian proyeksi bayangan

umbra adalah $62^{\circ} 58^{\prime} 36,91^{\prime \prime}$ di

atas ufuk.

d. Menghitung Arah Matahari $\left(\mathrm{A}_{\mathrm{o}}\right)$.
$\operatorname{Cotan} \mathrm{A}_{\mathrm{o}}=\tan \delta_{\mathrm{o}} \cdot \cos \varphi / \sin \left[\mathrm{t}_{\mathrm{o}}\right]$

$-\sin \varphi / \tan \left[\mathrm{t}_{\mathrm{o}}\right]$

Cotan $\mathrm{A}_{\mathrm{o}}=\tan 19^{\circ} 5^{\prime} 33,16^{\prime \prime} \cdot \cos$

$-7^{\circ} / \sin \left[-155^{\circ} 7^{\prime} 45^{\prime \prime}\right]-\sin -7^{\circ} /$

$\tan \left[-155^{\circ} 7^{\prime} 45^{\prime \prime}\right]$

$\mathrm{A}_{\mathrm{o}}=61^{\circ} 00^{\prime} \quad 52,4^{\prime \prime}$ UT (karena

hasil $A_{o}$ positif dan $t_{o}$ negatif)

Azimut Matahari $=61^{\circ} 00^{\prime} 52,4^{\prime}$

UTSB

Azimut bayangan umbra Bumi selalu berkebalikan dengan azimut Matahari sehingga azimut bayangan umbra Bumi $=61^{\circ} 00^{\prime}$ $52,4^{\prime \prime}+180^{\circ}=241^{\circ} 00^{\prime} 52,4^{\prime \prime}$ UTSB

e. Menghitung Sudut Waktu Bulan $\left(t_{(}\right)$

$\mathrm{t}_{\mathrm{C}}=\alpha_{\mathrm{o}}+\mathrm{t}_{\mathrm{o}}-\alpha_{\mathrm{c}}$

$\mathrm{t}_{\mathrm{c}}=127^{\circ} 0^{\prime} 38,23^{\prime \prime}+-155^{\circ} 7^{\prime} 45^{\prime \prime}$

$-306^{\circ} 3$ ' 1,73 '”

$\mathrm{t}_{(}=-334^{\circ} 10^{\prime} 8,5^{\prime \prime}$

f. Menghitung Ketinggian Bulan

$\operatorname{Sin} h_{(}=\sin \varphi \cdot \sin \delta_{(}+\cos \varphi \cdot \cos$ $\delta_{(} \cdot \cos \left[\mathrm{t}_{\mathrm{f}}\right]$

$\operatorname{Sin} \mathrm{h}_{(}=\sin -7^{\circ} \cdot \sin -19^{\circ} 6^{\prime} 56,23^{\prime \prime}$

$+\cos -7^{\circ} \cdot \cos -19^{\circ} 6^{\prime} 56,23^{\prime \prime} \cdot \cos$

[-334 $\left.14^{\circ}, 8,5^{\prime \prime}\right]$

$\mathrm{h}_{\mathrm{C}}=62^{\circ} 7^{\prime}, 53,32^{\prime \prime}$ di atas ufuk

g. Menghitung Azimut Bulan (A)

$\operatorname{Cotan} \mathrm{A}_{(}=\tan \delta_{(} \cdot \cos \varphi / \sin \left[\mathrm{t}_{\mathrm{C}}\right]-$ $\sin \varphi / \tan [\mathrm{t}]$ 


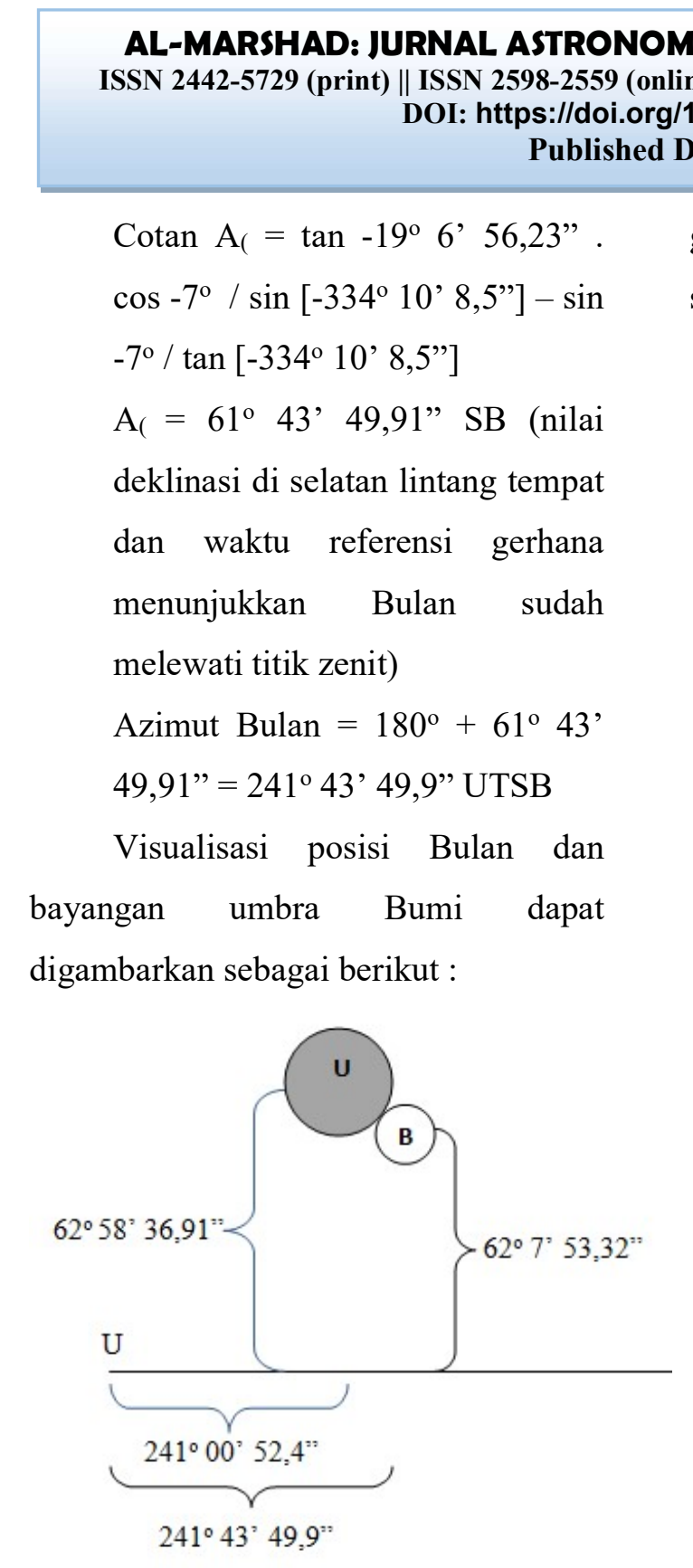

Jadi bayangan umbra Bumi mulai menyentuh piringan Bulan dari arah kiri serong ke atas seperti pada visualisasi di atas. Jika perhitungan ini diulang dengan waktu referensi yang berbeda, meliputi waktu awal total, akhir total, dan akhir gerhana, maka prediksi gerak bayangan gerhana Bulan akan tervisualisasikan sebagaimana gambar di bawah :
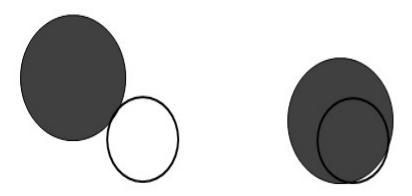

Mulai Gerhana

Mulai Total

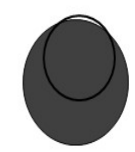

Akhir Total

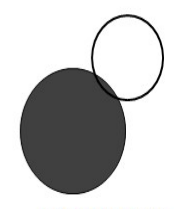

Akhir Gerhana

\section{G. Kesimpulan}

Perhitungan gerak bayangan

Bumi saat terjadi gerhana Bulan merupakan sistem perhitungan untuk mengetahui posisi Bulan dan proyeksi bayangan Bumi, yang mana diperoleh dari posisi kebalikan Matahari berada. Data yang dicari meliputi ketinggian dan azimut, kemudian divisualisasikan secara spesifik dan berkala menurut waktu refernsi terjadinya gerhana Bulan. Pada akhirnya dapat diketahui gerak bayangan gerhana Bulan dimulai dari arah bayangan Bumi beranjak masuk ke dalam piringan Bulan hingga keluar dari piringan Bulan sepenuhnya.[]

\section{Daftar Pustaka}

Anugraha, Rinto. (2012). Mekanika Benda Langit, Yogyakarta: Universitas Gadjah Mada.

Azhari, Susiknan. (2001) Ilmu Falak Teori dan Praktek, Yogyakarta : Lazuardi. 
Badan Hisab \& Rukyat Departemen Agama. (1981). Almanak Hisab Rukyat, Jakarta: Departemen Agama.

Direktorat Urusan Agama Islam dan Bimbingan Islam Kementerian Agama RI. (2017). Ephemeris Hisab Rukyat 2018, Jakarta : Kemenag RI.

Hambali, Slamet. (2013). Ilmu Falak Arah Kiblat Setiap Saat, Yogyakarta: Pustaka Ilmu. , (2012). Pengantar Ilmu Falak, Banyuwangi : Bismillah Publisher.

Izzan, Ahmad. (2013). Studi Ilmu Falak, Banten : Pustaka Aufa Media. Izzuddin, Ahmad. (2012). Ilmu Falak Praktis, Semarang: PT. Pustaka Rizki Putra.

Jamil, A. (2014). Ilmu Falak Teori \& Aplikasi, Jakarta: Amzah.

Khazin, Muhyiddin. (2004). Ilmu Falak dalam Teori dan Praktik, Yogyakarta : Buana Pustaka. , (2005). Kamus Ilmu

Falak, Yogyakarta : Buana Pustaka.

Rachim, Abdur. (tth). Perhitungan Awal Bulan, Yogyakarta: Jogja Astronomi Club. 